\title{
Distribution and Severity of Dry Root Rot of Chickpea Caused by Rhizoctonia bataticola in Parts of North Karnataka, India
}

\author{
Deepa $^{1 *}$, Gururaj Sunkad ${ }^{1}$, Mamta Sharma ${ }^{2}$, S.B. Mallesh ${ }^{1}$, \\ D.M. Mannur ${ }^{3}$ and A.G. Sreenivas ${ }^{4}$
}

${ }^{1}$ Department of Plant Pathology, University of Agricultural Sciences, Raichur-584104, Karnataka, India

${ }^{2}$ Department of Pulse Research, International Crops Research Institute for the Semi-Arid

Tropics, Patancheru 502 324, Andhra Pradesh, India

${ }^{3}$ Department of Genetics and plant Breeding, University of Agricultural Sciences, Raichur-584104, Karnataka, India

${ }^{4}$ Department of Agriculture Entomology, University of Agricultural Sciences, Raichur584104, Karnataka, India

*Corresponding author

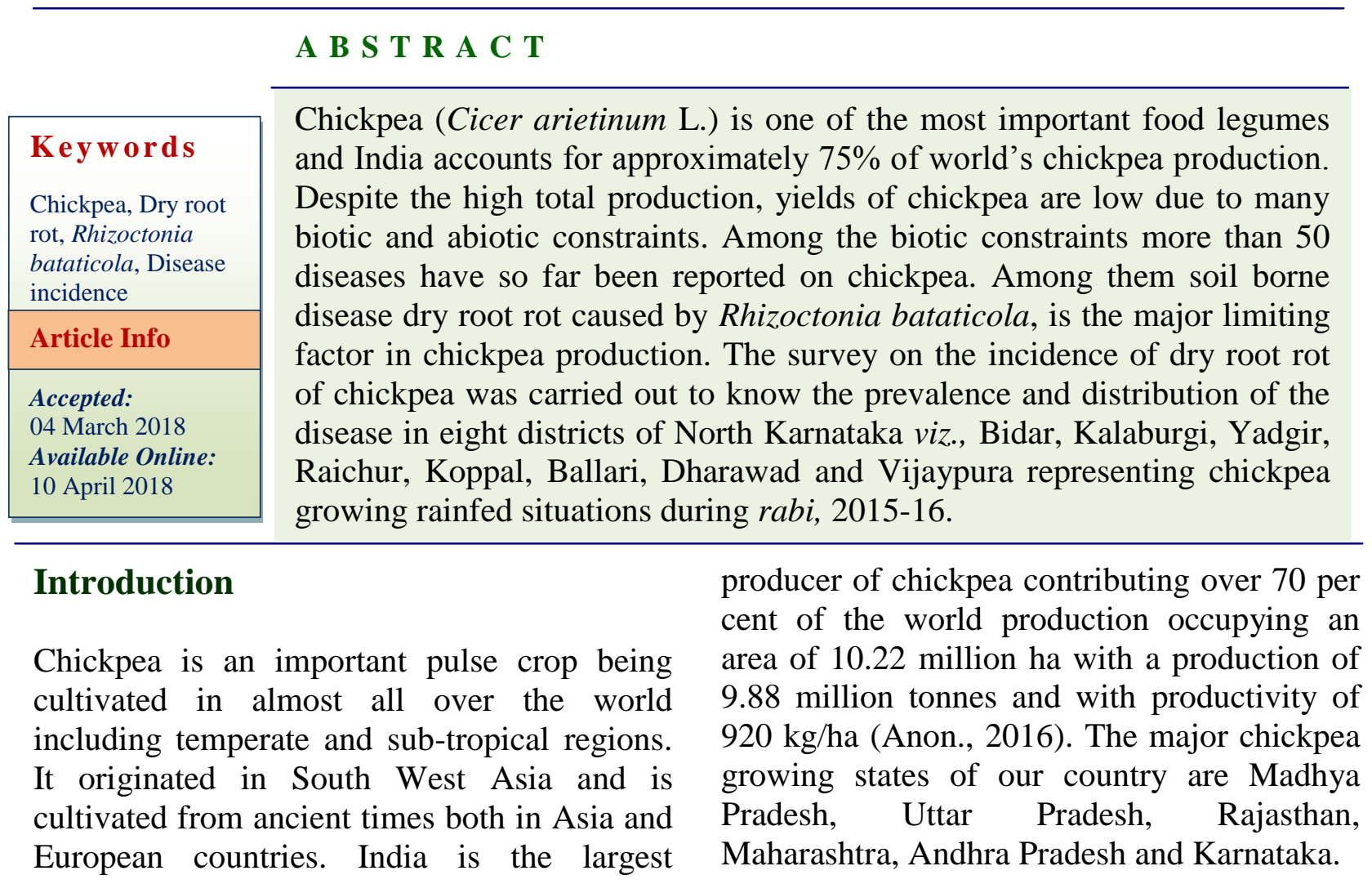


Rhizoctonia is a genus of anamorphic fungi in the order Cantharellales and family Ceratobasidiaceace. Rhizoctonia species do not produce spores, but are composed of hyphae and sclerotia (hyphal propagules), asexual stage of fungi, saprophytic, but some act as facultative plant pathogens causing commercially important crop diseases. The dry root rot in chickpea was first reported from India by Mitra (1931); later, the disease has been reported from most chickpeagrowing areas in India and other countries like Iran (Kaiser et al., 1968), the USA (Westerlund et al., 1974) and several countries in Asia and Africa (Nene et al., 1996). The disease was earlier known as "Rhizoctonia wilt" in chickpea; however, later it was named as "dry root rot". The dry root rot was not of much significance in chickpea earlier; however, it has become a major threat to chickpea production in recent years due to altered weather conditions, particularly on the account of longer drought spells. Higher temperature and soil moisture depletion during crop growth period particularly at preharvesting stage is predisposing chickpea to dry root rot (Sharma and Pande, 2013). Recent surveys conducted during 2010-2013 indicated widespread and increased incidence of dry root rot in the central and southern states of India (Ghosh et al., 2013). Disease was found irrespective of soil types, cropping system and cultivars used and incidence ranged from 5 to 50 per cent or more in badly infected soils.

Considering the severity and loss caused by $R$. bataticola, it was thought necessary to initiate systematic studies on emerging and destructive dry root rot disease problem occurring in different parts of Karnataka.

\section{Materials and Methods}

A roving survey was conducted to record the occurrence and distribution of dry root rot of chickpea in 8 districts of the major chickpea growing areas in North Karnataka viz., Bidar, Kalaburagi, Yadagiri, Raichur, Koppal, Ballari, Bijapur and Dharwad during rabi, 2015-16. In each districts, three taluks were selected, in each taluks minimum two villages were selected, in each village minimum three fields were selected and in each field, five plots of $10 \mathrm{~m}^{2}$ were selected and the incidence of disease was recorded after counting the diseased and healthy plants. While surveying, data on variety grown, soil type, plant protection measures taken, based on infected plants and total number of plants observed, disease incidence was calculated. Chickpea plants showing the typical dry root rot symptoms were collected from surveyed areas, packed in labeled paper bags and brought to the laboratory for isolation of the pathogen. Meantime, the co-ordinates of surveyed fields were also recorded with the help of GPS. Based on observations the disease incidence was calculated by following formula.

Number of plants infected Dry root rot incidence $(\%)=$---------- x 100

Total number of plants

\section{Results and Discussion}

A roving survey was conducted during rabi, 2015-16 in eight chickpea growing districts of North Karnataka. The per cent dry root rot incidence was recorded at 55-80 days old crop. The results indicated that the incidence was noticed in all the fields wherever the survey was conducted.

Results indicated that Bidar district recorded the mean dry root rot incidence of 25.87 per cent (Table 2). Highest dry root rot (34.20\%) was recorded in Madagatti village of Bhalki taluk followed by Humnabad village (32.11\%) and Gadgi $(30.32 \%)$ village of Bidar taluk and lowest incidence of $16.12 \%$ was recorded in Manhalli village of Bidar taluk (Table 1). 
Survey conducted in Kalaburgi district indicated that mean incidence of dry root rot was $35.54 \%$ for the two years (Table 2). Highest incidence of dry root rot $(45.55 \%)$ was observed in Bhusnur village of Aland taluk followed by Sannur village $(42.33 \%)$ of Kalaburgi taluk and Aland village of Aland taluk (40.00\%). While, Ijeri village of Jewargi taluk recorded least dry root rot of $24.56 \%$. (Table 1). Survey of Yadagiri district revealed that highest dry root rot was found in Bheemarayanagudi village $(11.10 \%)$ of Shahapur taluk followed by Malanoor (7.00\%) and Yadagiri $(5.60 \%)$ and least dry root rot was recorded in Aldhal village $(0.50 \%)$ of Shorapur taluk (Table 1). The mean incidence in Yadagiri district for dry root rot was 3.19\%. Among twelve villages in Raichur district, Huvinahadgi village of Devadurga taluk recorded highest dry root rot $(45.23 \%)$ followed by Jalahalli (36.44\%) village of Devadurga taluk and Kollur $(35.56 \%)$, the least dry root rot $(18.35 \%)$ was recorded in Bhupur village of Lingasugur. The district mean incidence of dry root rot was $31.20 \%$ for two years.

The mean incidence of Koppal district recorded $14.20 \%$ dry root rot (Table 2 ). The highest disease incidence $(23.00 \%)$ was found in Halagere village of Koppal taluk followed by Kuknoor village of Yelbarga taluk $(17.00 \%)$ and there was least incidence of dry root rot in the fields of Bewoor village $(08.00 \%)$ of Yelbarga taluk. The average incidence dry root rot in Ballari district was $13.98 \%$. Maximum incidence was observed in Belagallu village $(24.59 \%)$ of Ballari taluk followed by Kolagallu village of Ballari taluk (21.53\%) and Hansi village of Kudligi taluk $13.00 \%$. Least incidence was in Siraguppa village of Siraguppa taluk $(04.81 \%)$ during rabi, 2015-16 (Table 1). In Vijayapura district survey revealed that highest dry root rot (45.00\%) was found in Bableshwar village of Sindagi taluk followed by Kuntoji village
(34.35\%) of Muddebihal taluk and Golageri village $(32.85 \%)$ of Sindagi taluk and lowest was in Vijayapura village (17.39\%) of Vijayapura taluk. However, an average incidence for the district for two years survey is $29.09 \%$. Dharawad district recorded the mean incidence of dry root rot were 8.27 per cent. Survey was conducted in eight villages of Dharawad district, among them highest dry root rot $(12.35 \%)$ was found in Bhadrapur village followed by Tadhal village of Nargund taluk $(11.21 \%)$ and least dry root rot $(02.00 \%)$ was recorded in Dharwad village of Dharwad taluk (Table 1).

The data on mean incidence (Table 2) with respect to taluk over season indicated that the highest mean incidence of dry root rot was recorded in Aland taluk $(38.43 \%)$ of Kalaburgi district followed of Jewargi taluk $(34.56 \%)$ and Kalaburgi taluk (34.22\%) of Kalaburgi district. The least incidence of dry root rot $(2.40 \%)$ was recorded in Shorapur taluk of Yadagiri district.

The survey on the incidence of dry root rot of chickpea was carried out to know the prevalence and distribution of the disease in eight districts of North Karnataka viz., Bidar, Kalaburgi, Yadgir, Raichur, Koppal, Ballari, Dharawad and Vijaypura representing chickpea growing rainfed situations. Survey of the disease over a period of time provides information about the intensity with which it affects the yield. In addition, it is a source of information about severity of disease in relation to soil environment and edaphic factors. In the present study, the data on survey revealed that, the dry root rot incidence varied from locality to locality. This may be due to varieties grown, environmental conditions viz., relative humidity, temperature and soil moisture content, cropping pattern like maize-chickpea, bajra-chickpea and chickpea and chickpea and buildup of inoculum. 
Table.1 Incidence of dry root rot of chickpea in major chickpea growing districts of North Karnataka during rabi, 2015-16

\begin{tabular}{|c|c|c|c|c|c|c|c|}
\hline District & Taluks & Villages & $\begin{array}{l}\text { No. of } \\
\text { fields }\end{array}$ & Variety & $\begin{array}{c}\text { Seed } \\
\text { treatment }\end{array}$ & Soil type & $\begin{array}{c}\text { Disease } \\
\text { incidence }(\%)\end{array}$ \\
\hline \multirow[t]{11}{*}{ Bidar } & \multirow[t]{4}{*}{ Bidar } & Bidar & 3 & JG-11 & Trichoderma & Black & 26.75 \\
\hline & & Andura & 3 & A-1 & Trichoderma & Black & 28.23 \\
\hline & & Manhalli & 3 & A-1 & No & Red & 16.12 \\
\hline & & Gadgi & 3 & A-1 & No & Black & 30.32 \\
\hline & \multirow[t]{3}{*}{ Bhalki } & Halahalli & 3 & A-1 & No & Black & 20.2 \\
\hline & & Madgatti & 3 & A-1 & No & Black & 34.20 \\
\hline & & Godihiperga & 3 & A-1 & Trichoderma & Clay loamy & 22.80 \\
\hline & \multirow[t]{4}{*}{ Humanabad } & Humanabad & 3 & JG-11 & No & Black & 32.11 \\
\hline & & Sanahalliked & 3 & JG-11 & Trichoderma & Red & 25.35 \\
\hline & & Chitguppa & 3 & JG-11 & No & Red & 25.00 \\
\hline & & Bachnal & 3 & JG-11 & No & Red & 23.55 \\
\hline \multicolumn{7}{|c|}{ Mean } & 25.87 \\
\hline \multirow[t]{14}{*}{ Kalaburgi } & \multirow{5}{*}{ Kalaburgi } & Kalaburgi & 3 & JG-11 & Trichoderma & Black & 35.25 \\
\hline & & Kadagancha & 3 & JG-11 & No & Black & 30.10 \\
\hline & & Itga Khandal & 3 & A-1 & No & Black & 37.45 \\
\hline & & Sannur & 3 & JG-11 & No & Black & 42.33 \\
\hline & & Kamalapur & 3 & JG-11 & No & Black & 26.00 \\
\hline & \multirow[t]{4}{*}{ Aland } & Aland & 3 & A-1 & Trichoderma & Black & 40.00 \\
\hline & & Bhusnur & 3 & A-1 & No & Black & 45.55 \\
\hline & & Tadola & 3 & JG-11 & No & Black & 33.00 \\
\hline & & Khajuri & 3 & A-1 & No & Black & 35.20 \\
\hline & \multirow[t]{5}{*}{ Jewargi } & Raddewadgi & 3 & $\begin{array}{l}\text { MNK-1, } \\
\text { JG-11 }\end{array}$ & Trichoderma & Black & 32.80 \\
\hline & & Jewargi & 3 & JG-11 & No & Black & 35.65 \\
\hline & & Andola & 3 & JG-11 & No & Black & 39.89 \\
\hline & & Ijeri & 3 & JG-11 & No & Black & 24.56 \\
\hline & & Nelogi & 3 & JG-11 & No & Black & 39.90 \\
\hline \multicolumn{7}{|c|}{ Mean } & 35.54 \\
\hline District & Taluks & Villages & $\begin{array}{l}\text { No. of } \\
\text { fields }\end{array}$ & Variety & $\begin{array}{c}\text { Seed } \\
\text { treatment }\end{array}$ & Soil type & $\begin{array}{c}\text { Disease } \\
\text { incidence (\%) }\end{array}$ \\
\hline \multirow[t]{14}{*}{ Yadagiri } & \multirow[t]{4}{*}{ Yadagiri } & Yadagiri & & A-1 & No & Black & 5.60 \\
\hline & & Mailapur & 3 & JG-11 & No & clay & 1.60 \\
\hline & & Munderga & 3 & JG-11 & No & Red & 1.0 \\
\hline & & Gurmitkal & 3 & A-1 & No & Black & 3.23 \\
\hline & \multirow[t]{4}{*}{ Shahapur } & $\begin{array}{l}\text { Bheemarayangu } \\
\text { di }\end{array}$ & 3 & A-1 & Trichoderma & Back & 11.10 \\
\hline & & Vibhutihalli & 3 & JG-11 & No & Clay loamy & 2.65 \\
\hline & & Gogi & 3 & A-1 & No & Clay loamy & 3.00 \\
\hline & & Madriki & 3 & JG-11 & No & Black & 1.55 \\
\hline & \multirow[t]{6}{*}{ Shorapur } & Malanoor & 3 & A-1 & No & Black & 7.00 \\
\hline & & Devapur & 3 & JG-11 & No & Black & 3.15 \\
\hline & & Tintani & 3 & JG-11 & No & Red & 1.10 \\
\hline & & Kakkeri & 3 & JG-11 & No & Red & 2.15 \\
\hline & & Manjalapur & 3 & JG-11 & No & Red & 1.12 \\
\hline & & Aldahal & 3 & JG-11 & No & Red & 0.50 \\
\hline & & & Mean & & & & 3.19 \\
\hline
\end{tabular}




\begin{tabular}{|c|c|c|c|c|c|c|c|}
\hline \multirow[t]{12}{*}{ Raichur } & \multirow[t]{5}{*}{ Raichur } & Raichur & & $\begin{array}{l}\text { MNK-1 } \\
\text { JG-11 }\end{array}$ & Trichoderma & Clay loamy & 32.15 \\
\hline & & Kallur & 3 & A-1 & No & Black & 30.45 \\
\hline & & Kalmala & 3 & JG-11 & No & Black & 34.5 \\
\hline & & Kasbe camp & 3 & JG-11 & No & Black & 26.00 \\
\hline & & Sirawar & 3 & A-1 & No & Black & 35.35 \\
\hline & \multirow{3}{*}{ Lingasugur } & Bhupur & 3 & JG-11 & No & Red & 18.35 \\
\hline & & Honnahalli & 3 & A-1 & No & Black & 26.44 \\
\hline & & Hatti & 3 & JG-11 & Carbendazim & Clay loamy & 21.15 \\
\hline & \multirow[t]{4}{*}{ Devadurga } & Masarakal & 3 & A-1 & No & Black & 32.89 \\
\hline & & Jalahalli & 3 & A-1 & No & Black & 36.44 \\
\hline & & Kollur (M) & 3 & A-1 & No & Black & 35.56 \\
\hline & & Huvinahadgi & 3 & A-1 & No & Black & 45.23 \\
\hline \multicolumn{7}{|c|}{ Mean } & 31.20 \\
\hline District & Taluks & Villages & $\begin{array}{l}\text { No. of } \\
\text { fields }\end{array}$ & Variety & $\begin{array}{c}\text { Seed } \\
\text { treatment }\end{array}$ & Soil type & $\begin{array}{c}\text { Disease } \\
\text { incidence }(\%)\end{array}$ \\
\hline \multirow[t]{6}{*}{ Koppal } & \multirow[t]{2}{*}{ Koppal } & Hyati & 3 & JG-11 & No & Clay loamy & 12.00 \\
\hline & & Halagere & 3 & A-1 & No & Black & 23.00 \\
\hline & \multirow[t]{2}{*}{ Kushtagi } & Kyadiguppa & 3 & A-1 & No & Black & 15.00 \\
\hline & & Matur & 3 & JG-11 & No & Black & 10.23 \\
\hline & \multirow[t]{2}{*}{ Yelbarga } & Bewoor & 3 & JG-11 & No & Red & 08.00 \\
\hline & & Kuknoor & 3 & JG-11 & No & Black & 17.00 \\
\hline \multicolumn{7}{|c|}{ Mean } & 14.20 \\
\hline \multirow[t]{6}{*}{ Ballari } & \multirow[t]{2}{*}{ Ballari } & Kolagallu & 3 & JG-11 & No & Clay loamy & 21.53 \\
\hline & & Belagallu & 3 & JG-11 & No & Black & 24.59 \\
\hline & \multirow[t]{2}{*}{ Siraguppa } & Siraguppa & 3 & JG-11 & No & Red & 04.81 \\
\hline & & Halekota & 3 & A-1 & Trichoderma & Black & 11.00 \\
\hline & \multirow[t]{2}{*}{ Kudligi } & Kudligi & 3 & A-1 & No & Black & 09.00 \\
\hline & & Hansi & 3 & A-1 & No & Black & 13.00 \\
\hline \multicolumn{7}{|c|}{ Mean } & 13.98 \\
\hline \multirow{8}{*}{$\begin{array}{c}\text { Vijayapur } \\
\text { a }\end{array}$} & \multirow[t]{3}{*}{ Vijayapura } & Vijayapura & 3 & JG-11 & Trichoderma & Black & 17.39 \\
\hline & & Arakeri & 3 & JG-11 & No & Black & 21.45 \\
\hline & & Jalageri & 3 & A-1 & No & Black & 25.49 \\
\hline & \multirow[t]{2}{*}{ Muddebihal } & Kuntoji & 3 & A-1 & No & Clay loamy & 34.35 \\
\hline & & Gangur & 3 & A-1 & No & Black & 26.25 \\
\hline & \multirow[t]{3}{*}{ Sindagi } & Sindagi & 3 & A-1 & No & Black & 29.5 \\
\hline & & Golageri & 3 & A-1 & No & Black & 32.85 \\
\hline & & Bableshwar & 3 & A-1 & No & Black & 45.00 \\
\hline \multicolumn{7}{|c|}{ Mean } & 29.09 \\
\hline \multirow[t]{8}{*}{ Dharwad } & \multirow[t]{3}{*}{ Dharwad } & Dharwad & 3 & JG-11 & Trichoderma & Red & 02.00 \\
\hline & & Yettingudda & 3 & JG-11 & No & Black & 08.23 \\
\hline & & Kallapur & 3 & JG-11 & Trichoderma & Red & 05.00 \\
\hline & Nargund & Nargund & 3 & A-1 & No & Black & 10.23 \\
\hline & & Tadhal & 3 & A-1 & No & Red & 11.21 \\
\hline & Navalgund & Yamanur & 3 & A-1 & No & Black & 06.00 \\
\hline & & Bhadrapur & 3 & A-1 & No & Black & 12.35 \\
\hline & & Javoor & 3 & A-1 & No & Black & 11.15 \\
\hline & & & Mean & & & & 8.27 \\
\hline & & & otal Me & & & & 23.72 \\
\hline
\end{tabular}


Table.2 Talukwise incidence of dry root rot of chickpea in parts of North Karnataka during rabi, 2015-16

\begin{tabular}{|c|c|c|c|}
\hline Sl. No. & District & Taluks & Dry root rot incidence $(\%)$ \\
\hline \multirow[t]{3}{*}{1} & \multirow{3}{*}{ Bidar } & Bidar & 25.35 \\
\hline & & Bhalki & 25.73 \\
\hline & & Humanabad & 26.50 \\
\hline & & Mean & 25.87 \\
\hline \multirow[t]{3}{*}{2} & \multirow[t]{3}{*}{ Kalaburagi } & Kalaburagi & 34.22 \\
\hline & & Aland & 38.43 \\
\hline & & Jewargi & 34.56 \\
\hline & & Mean & 35.73 \\
\hline \multirow[t]{3}{*}{3} & \multirow[t]{3}{*}{ Yadagiri } & Yadagiri & 2.85 \\
\hline & & Shahapur & 4.57 \\
\hline & & Shorapur & 2.40 \\
\hline & & Mean & 3.27 \\
\hline \multirow[t]{3}{*}{4} & \multirow[t]{3}{*}{ Raichur } & Raichur & 31.69 \\
\hline & & Lingasugur & 21.98 \\
\hline & & Devadurga & 37.53 \\
\hline & & Mean & 30.40 \\
\hline \multirow[t]{3}{*}{5} & \multirow[t]{3}{*}{ Koppal } & Koppal & 17.50 \\
\hline & & Kustagi & 12.61 \\
\hline & & Yelaburga & 12.50 \\
\hline & & Mean & 14.20 \\
\hline \multirow[t]{3}{*}{6} & \multirow[t]{3}{*}{ Ballari } & Ballari & 23.06 \\
\hline & & Siraguppa & 7.90 \\
\hline & & Kudligi & 11.00 \\
\hline & & Mean & 13.98 \\
\hline \multirow[t]{3}{*}{7} & \multirow[t]{3}{*}{ Vijayapura } & Vijayapura & 21.44 \\
\hline & & Muddebihal & 30.30 \\
\hline & & Sindagi & 35.95 \\
\hline & & Mean & 29.23 \\
\hline \multirow[t]{3}{*}{8} & \multirow[t]{3}{*}{ Dharawad } & Dharawad & 5.07 \\
\hline & & Nargund & 10.72 \\
\hline & & Navalagund & 9.83 \\
\hline \multirow{2}{*}{\multicolumn{3}{|c|}{ Overall mean incidence }} & 8.54 \\
\hline & & & 38.72 \\
\hline
\end{tabular}

Even, it could also be attributed to the existence of variability or pathogenic diversity present in the fungus. In rabi 201516, the incidence of dry root rot was maximum $(45.55 \%)$ in Bhusnur village of Aland taluk, Kalaburgi district followed by
Huvinahadgi village of Devadurga taluk, Raichur district, recorded highest dry root rot $(45.23 \%)$. The least was noticed in Aldahal $(1.00 \%)$ and Munderga village $(1.00 \%)$ of Yadagiri taluk. Similarly, Veerendra Kumar (2004) noticed an incidence of 9.97 per cent 
dry root rot of chickpea in Gulbarga followed by Raichur $(5.16 \%)$ and Bidar $(4.28 \%)$. The highest incidence was 12.24 per cent in Chittapur of Gulbarga and least was in one of the locations of Raichur (3.21\%). Monocropping with closer spacing and also drought and high temperature increased the vulnerability of the crop and enhanced the aggressiveness of the pathogen. The present findings are also supported by Garrett et al., (2006); Kaur et al., (2012) and Sharma et al., (2016). Srinivas (2016) reported through survey that percent disease incidence was ranged from 6.67 to 15.33 per cent in Karnataka and 0.67 to 3.33 per cent in Andhra Pradesh at different locations.

\section{References}

Anonymous, 2016. Annual kharif pulses group meet. All India co-ordinated research project of pigeonpea (ICAR), $22^{\text {nd }}-24^{\text {th }}$ May, P: 406.

Garrett, K. A., Dendy, S. P., Frank, E. E., Rouse, M. N. and Travers, S. E., 2006. Climate change effects on plant disease: genomes to ecosystems. Ann. Rev. Phytopath., 44:489-509.

Ghosh, R., Sharma, M., Telangre, R. and Pande, S., 2013. Occurrence and distribution of chickpea diseases in central and southern parts of India. American J. Pl. Sci., 4: 940-944.

Kaiser, W. J., Danesh, D., Okhovat, M. and Mossahebi, H., 1968. Diseases of pulse crops (edible legumes) in Iran. Plant Dis Rep., 52: 687-691.
Kaur, S., Chauhan, V. B., Singh, J. P. and Singh, R. B., 2012. Status of Macrophomina stem canker disease of pigeonpea in eastern Uttar Pradesh. $J$. Food Legumes, 25(1): 76-78.

Mitra, M., 1931. Report of the imperial mycologist. Sci. Rep. Agri. Res. Inst., pp 58-71.

Nene, Y. L., Sheila, V. K. and Sharma, S. B., 1996. A World list of chickpea and pigeonpea pathogens. ICRISAT, $5^{\text {th }}$ edition. 1-27.

Sharma, M. and Pande, S., 2013. Unraveling effects of temperature and soil moisture stress response on development of dry root rot [Rhizoctonia bataticola (Taub.)] Butler in chickpea. American J. Pl. Sci., 4: 584-589.

Sharma, M., Ghosh, R. and Pande, S., 2016. Dry root rot (Rhizoctonia bataticola (Taub.) Butler): an emerging disease of chickpea where do we stand? Arch. Phytopath. Plt. Prot., 48:13-16.

Srinivas, P., 2016. Studies on dry root rot [Rhizoctonia bataticola (taub.) butler] of chickpea (cicer arietinum). Ph.D., Thesis, Professor Jayashankar Telangana State Agricultural University, India.

Veerendra Kumar, K. V., 2004. Studies on dry root rot disease of chickpea caused by $R$. bataticola. M. Sc. (Agri) Thesis Uni. Agric. Sci., Dharwad (India).

Westerlund, F. V., Cambell, R. N. and Kimble, K. A., 1974. Fungal root rots and wilt of chickpea in California. Phytopathol., 664:432-436.

\section{How to cite this article:}

Deepa, Gururaj Sunkad, Mamta Sharma, S.B. Mallesh, D.M. Mannur and Sreenivas, A.G. 2018. Distribution and Severity of Dry Root Rot of Chickpea Caused by Rhizoctonia bataticola in Parts of North Karnataka, India. Int.J.Curr.Microbiol.App.Sci. 7(04): 194-200. doi: https://doi.org/10.20546/ijcmas.2018.704.021 